\title{
Randomness and Providence: Defining the Problem(s)
}

\author{
Aaron M. Griffith and Arash Naraghi
}

\begin{abstract}
3.1 INTRODUCTION
Traditional monotheistic religions (Judaism, Christianity, and Islam) all express a commitment to God's providence (from the Latin providere, to foresee or to provide for) over the created world. While different conceptions of God's providence are found in and among these traditions, they each affirm that God governs and controls the whole of creation, including the lives of individuals, with perfect power, goodness, and knowledge. However, the created world appears to be full of randomness. Many events are unpredictable and lack a discernable pattern, purpose, or cause. From the sub-atomic level, to the human social world, to the formation of galaxies, creation seems to display randomness that cannot be explained simply by human ignorance. Such randomness appears to be part of the very
\end{abstract}

\section{A. M. Griffith $(\bowtie)$}

The College of William \& Mary, Williamsburg, VA, USA

e-mail: amgriffith@wm.edu

\section{A. Naraghi}

Moravian College, Bethlehem, PA, USA

e-mail: naraghia@moravian.edu

(C) The Author(s) 2022

K. J. Clark, J. Koperski (eds.), Abrahamic Reflections on

Randomness and Providence, https://doi.org/10.1007/978-3-030-75797-7_3 
fabric of the world itself. Indeed, our best contemporary science-quantum mechanics, for example-seems to indicate that some events are in principle unpredictable.

Such randomness is prima facie incompatible with God's providence over creation. The tension is easy to appreciate. Random events seem not to be controllable and not part of any plan, much less any good plan. But God's providence consists in his ability to control and foresee the unfolding of events in such a way that they lead to a good and meaningful goal. If this tension is genuine, it would be a serious worry for traditional Abrahamic monotheism. If the world is ungovernable, then we have reason to doubt that God is provident, and hence to doubt that God exists. For God's providence is tied up with his other essential attributes: omnipotence, omniscience, omnibenevolence. Moreover, the challenge posed by randomness for the believer is that it calls into question the purposiveness of events as well as God's ability to fulfill his promises. Trust in God's plan and care for his creatures looks to be eroded by randomness in the world.

As compelling as this problem might initially seem, we argue that it is difficult to formulate an uncontroversial version of the problem of randomness for God's providence given the various empirical and theological variables at play. This chapter is primarily an attempt to locate the numerous choice points (empirically and theologically) that could generate a tension or incompatibility between randomness and God's providence. We begin by outlining different ways in which ontological randomness can be understood. We then consider various conceptions of God's providence, which differ with respect to the nature of God's foreknowledge, power, and purpose for creation. With these variables on the table we go on to develop a number of arguments for thinking that randomness is incompatible with God's providence and consider some replies from different conceptions of providence.

\subsection{Ontological Randomness}

'Random' is a label applied to a number of importantly different phenomena. These include outcomes of games of chance, sequences of numbers lacking a pattern, coincidence of independent events, methods for sampling populations, radioactive decay, quantum indeterminacy, genetic mutation, and chaotic non-linear systems (Bradley 2012). The sort of randomness we are concerned with is ontological rather than epistemological. Ontological randomness is randomness in being itself, irrespective of 
human cognition and its limits. What appears to us to be indeterminate, unpredictable, or purposeless is there in the world itself, not merely our understanding of the world. We distinguish two broad forms of ontological randomness: one in terms of indeterminism and another in terms of purposelessness. We think this distinction can help capture the common uses of 'randomness' found in the literature.

\subsubsection{Randomness as Indeterminism}

The first form of ontological randomness is defined in terms of indeterminism. A random event, in this sense, is the outcome of an indeterministic process. That is to say:

Indeterministic Randomness: Event $\mathrm{E}$ is random $_{I}$ iff $\mathrm{E}$ occurs and $\mathrm{E}$ 's occurrence is not determined to be part of a unique future, that is, both $\mathrm{E}$ and not-E are outcomes compatible with the way things are up to E's occurrence.

Indeterminism has implications for predictability: if an event $\mathrm{E}$ is the result of an indeterministic process in the above sense, then there is no way to predict with certainty that $\mathrm{E}$ will occur. ${ }^{1}$ Being the result of an indeterministic process explains why E's occurrence could not have been predicted with certainty on the basis of a complete description of events up to E's occurrence.

It is important to distinguish two readings of Indeterministic Randomness. On the one hand, a random ${ }_{I}$ event may be indeterminate in the strongest possible sense, that is, one that is indeterminate with respect to any factors whatsoever up to the event's occurrence. Such events are not determined by either physical or 'metaphysical' or 'supernatural' causes, for example, God's direct action in the world. On the other hand, a ran$\operatorname{dom}_{I}$ event may be indeterminate with respect to physical factors. Such events may, therefore, be determined by metaphysical or supernatural

\footnotetext{
${ }^{1}$ To predict $\mathrm{E}$, as we'll understand it here, is a matter of knowing that $\mathrm{E}$ will occur on the basis of complete knowledge of the world prior to E's occurrence and the relevant laws. Moreover, if an event $\mathrm{E}$ is predicted, then $\mathrm{E}$ occurs. Although all indeterministic events are unpredictable in this sense, we do not assume that all unpredictable events are indeterministic. Chaotic systems can involve events that are all causally determined despite the system's unpredictability due to extreme sensitivity on initial conditions. See Bradley $(2012,78)$.
} 
factors despite their lack of physical determination. Call random $_{I}$ events that are entirely indeterministic, 'metaphysically random ${ }_{I}$ ' and events that are indeterministic with respect to physical factors, 'physically random ${ }_{I}$ '

Metaphysical Randomness: Event $\mathrm{E}$ is metaphysically $\operatorname{random}_{I}$ iff $\mathrm{E}$ occurs and E's occurrence is not determined to be part of a unique future by anything whatsoever, that is, both $\mathrm{E}$ and not-E are outcomes compatible with all factors up to E's occurrence.

Metaphysically random ${ }_{I}$ events would be, as Clark (2014) puts it, "in principle unpredictable."

Physical Randomness: $\quad$ Event $\mathrm{E}$ is physically random iff $_{I} \mathrm{E}$ occurs and E's occurrence is not determined to be part of a unique future by any physical factors, that is, both $\mathrm{E}$ and not-E are outcomes compatible with the laws of nature and the state of the world up to E's occurrence. ${ }^{2}$

Random ${ }_{I}$ events cannot be predicted with certainty. Of course, inability to predict with certainty is not incompatible with ability to predict with high probability. Random ${ }_{I}$ events have an objective probability of occurring less than 1 and greater than 0 . There may be antecedent factors that make such an event more likely to occur. Knowing the antecedent factors that make the event more or less likely may allow us to predict its occurrence with high probability.

Given this, it is worthwhile articulating a notion of $\operatorname{randomness}_{I}$ in which random events are not predictable in the sense that they are events whose occurrence cannot be predicted with high probability. Not only would such an event be the result of an indeterministic process, but there would also be no connection between the probability of the event and other prior events. Such an event would be arbitrary:

${ }^{2}$ If a physically random $\mathrm{I}_{\mathrm{I}}$ event is determined by something non-physical, for example,

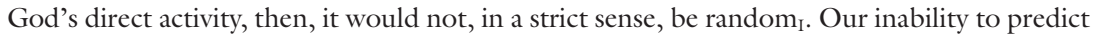
such an event would simply be due to our ignorance of the metaphysical cause of the event and hence be an example of epistemic randomness. On the other hand, if the whole of reality is physical, then all physically random ${ }_{I}$ events would thereby also be metaphysically random . $_{\text {. }}$ 
Arbitrary Randomness: $\quad$ Event $\mathrm{E}$ is arbitrarily random $_{I}$ iff $\mathrm{E}$ occurs and E's occurrence is not determined to be part of a unique future and the probability of E's occurrence is completely independent of the occurrence of any event prior to E's occurrence.

Many physicists hold that there is ontological randomness at the quantum level (especially those holding to the Copenhagen interpretation of quantum mechanics). They think that Bell's Theorem provides strong evidence that some quantum events-for example, determining whether an electron passing through a beam splitter has an up-spin or down-spin-are in principle unpredictable rather than unpredictable because of our ignorance of hidden variables. Such quantum events appear to be examples of randomness ${ }_{I}$. They are not predictable with certainty, though they may be predictable with high probability. These physicists deny that such events are arbitrarily random $_{I}$, for the occurrence of these events are not arbitrary but rather have a certain probability of occurring and are governed by statistical laws.

Libertarian free will might also be thought to involve randomness ${ }_{I}$. Free actions, according to the libertarian, are the results of indeterministic processes: their occurrence or non-occurrence is compatible with the state of the world immediately prior to their occurrence. They are not predictable with certainty on the basis of knowledge of the world up to the time of their occurrence. However, most libertarians want to avoid calling free actions random because it connotes arbitrariness. We think they may still accept that free action involves Indeterministic Randomness as long as it does not involve Arbitrary Randomness ${ }_{I}$.

\subsubsection{Randomness as Purposelessness}

The second form of ontological randomness is defined in terms of lacking a purpose. Events with a purpose are brought about for a reason or play a role in realizing some goal, non-accidentally. Peter van Inwagen holds that an event is a 'chance' event if it is "without purpose or significance; it is not a part of anyone's plan; it serves no end; it might very well not have been. 'Why did that happen?' the only right answer is: 'There is no reason or explanation; it just happened" (1988, 50-51). One way to capture this idea is to sever the connection between the probability of the event and its contribution to a purpose or goal. An event does not serve a purpose if there is no connection between the probability of the event's occurrence and its contribution to that purpose. Hence, 
Purposeless Randomness: Event $\mathrm{E}$ is random $_{P}$ iff $\mathrm{E}$ occurs and the probability that $\mathrm{E}$ occurs is completely independent of its (non-) contribution to any purpose.

Since the examples we will consider below concern specific purposes or goals, it is helpful to have a relativized notion of randomness $_{B}$ that is, a notion of randomness with respect to some particular purpose or goal:

Relative Randomness: Event $\mathrm{E}$ is relatively random $_{P}$ with respect to some purpose $\mathrm{P}$ iff $\mathrm{E}$ occurs and the probability that $\mathrm{E}$ occurs is completely independent of its (non-) contribution to $\mathrm{P}$.

If $\mathrm{E}$ is random $_{P}$ with regard to purpose $\mathrm{P}$, then E's occurrence is not for the sake of $\mathrm{P}$. According to evolutionary biology, mutations are random in the sense that they do not occur for the sake of the fitness of the individual (or species). Mutations may have genetic causes and be more or less predictable, but their purpose is not the survival of the organism. So, at least with respect to the fitness of organisms, such mutations are examples of Relative Randomness ${ }_{P}$.

Having defined two general categories of randomness- randomness $_{I}$ and randomness $s_{P}$-it is worth noting that the two categories cut across each other. Some random ${ }_{I}$ events also lack a purpose, that is, they are ran$\operatorname{dom}_{P}$. Arbitrarily random events, for example, 'just happen' and so are not produced for the sake of anything else. But other random ${ }_{I}$ events may have a purpose. If there is libertarian free will, then there are events, for example, an agent's freely chosen action, that are the result of an indeterministic process but occur for the sake of some purpose, that is, whatever goal or intention the agent had in mind. Moreover, it is possible for an event to be purposeless while still being the result of a deterministic process, that is, non-random ${ }_{I}$. Such an event may be the result of a deterministic process despite not serving any purpose. In sum, some but not all random $_{I}$ events are random ${ }_{P}$ events and some but not all random ${ }_{P}$ events are random ${ }_{I}$ events.

It should be noted that we will not argue for the actual existence of any examples of ontological randomness. So, we do not take a stand on whether the mathematical equations used to represent quantum states is best interpreted according to the Copenhagen (indeterministic) or Bohmian (deterministic) interpretations. And we do not insist that 
genuinely free actions are libertarian free actions. Ours is a conceptual project exploring the compatibility or incompatibility of ontological randomness and God's providence. The question is, is it possible for God to be provident in a world containing ontological randomness (whether or not such randomness is actual)?

\subsection{Divine Providence}

Scott Davison writes, "In the most basic sense, a person is provident over something if and only if that person exercises control over it, based upon knowledge, for a good purpose" (1999). Davison's gloss identifies the key elements in traditional monotheistic accounts of providence, namely, God's power, God's knowledge, and God's goodness with respect to his creation. Many proponents of the doctrine agree on this much. But in the details of the doctrine we find substantial disagreement about how it should be articulated. Three broad approaches to divine providence can be distinguished: Super Meticulous Providence, Meticulous Providence, and General Providence.

\subsubsection{Super Meticulous Providence}

Under this heading we include 'Theological Determinism,' which is the view that "God unconditionally decrees every event that occurs in the history of the world" (Vicens 2014). God determines that all events happen as they do, either by directly causing them to happen or by initiating a sequence of events such that each event is necessitated (Judisch 2012). What is common to Super Meticulous views of providence is that nothing happens that is not intended or permitted by God. Each event that happens has a purpose and plays a specific role in God's ultimate plan for creation. This plan is wise and loving in execution and realization. On Super Meticulous views, God has complete and detailed knowledge of the actual past, present, and future. This includes foreknowledge of what creatures will freely do. ${ }^{3}$ This is the most exacting form of 'risk-free' providence, for quite literally nothing is outside of God's control; God's plan will be

\footnotetext{
${ }^{3}$ Proponents of Super Meticulous Providence will be determinists and hence endorse a compatibilist view of free will. They may also attribute to God knowledge of the conditionals regarding what creatures would freely do in various circumstances. However, they will deny, as the Molinist holds, that such truths are true independent of God's will (Flint 1998, 86).
} 
realized exactly as God intends, with no chance of failure or alteration. Super Meticulous views of providence are found in Calvin and Edwards in Christianity, among the Ash'ari theologians in Islam, and among Hasidic thinkers like Mordechai Yosef Leiner in Judaism. Although controversial, we include here Aquinas' view on which God works through secondary (created) causes, concurring or cooperating with them to bring about each new event and state of the world in time.

\subsubsection{Meticulous Providence}

Like Super Meticulous views, Meticulous Providence depicts God's relation to creation as 'risk-free.' While nothing is outside of God's knowledge, God allows some level of genuine agency, autonomy, or indeterminism in his creation. In Islam, versions of Meticulous Providence are defended by Mu'tazili theologians and some philosophers such as Farabi (tenth century). In Judaism, Maimonides appears to be an advocate of Meticulous Providence (1904, 161, 285-287). In Christianity, Molinism is a prime example of Meticulous Providence. According to Molinists, God ordains all events to happen. For some events, God is the ultimate sufficient cause, while for others, God casually brings about circumstances under which events will take place (even if not with necessity) (Rhoda 2010, 283). What is crucial for Molinists is that God has 'middle knowledge' of contingently true conditionals concerning which events will nondeterministically occur in a given set of circumstances. Call these 'counterfactuals of indeterminism' (cf. Flint 1998, 40). Among these are 'counterfactuals of creaturely freedom' (Flint 1998, 46), which are contingently true conditionals concerning what creatures will freely do when put in certain circumstances. Meticulous Providence allows for indeterminate events in creation but insists that God knows (and promotes and permits) the outcomes of such events. If God has middle knowledge, then prior to creating he can decide which world to create among the feasible alternatives $^{4}$ and know with certainty how things will turn out in each alternative. Defenders of Meticulous Providence hold that God's plan is

\footnotetext{
${ }^{4}$ According to Flint (1998, 51ff.) feasible worlds are those that God can actualize, where that is determined by the complete set of counterfactuals of creaturely freedom God knows to be true. If God knows the counterfactual $(\mathrm{C} \rightarrow \mathrm{A})$ is true, then he cannot actualize a world — such a world would be 'infeasible' - in which circumstance C obtains, yet action A is not performed.
} 
loving and that nothing can happen that will jeopardize God realizing his plan (though they may disagree amongst themselves about how specific God's plan is).

\subsubsection{General Providence}

Adherents of General Providence deny that God determines (directly or indirectly) all events to happen. They also deny that God has knowledge of certain things, precisely because there is no knowledge of such things to be had. For example, according to Open Theism, God has exhaustive and complete knowledge of the past and present but not of the actual future, since there is no actual future according to most Open Theists. ${ }^{5}$ There are some events, for example, the freely chosen actions of human beings, of which God has neither foreknowledge nor middle knowledge. God may know with certainty that some events will occur, such as those that are necessitated by the present and the laws of nature. But Open Theists hold that many future events are indeterminate and may hold that God only knows that future events have a certain probability (less than $l$ and greater than 0 ) of occurring. On this view, God's governance involves his reaction or response to his creatures' actions that, in some cases, he does not foreknow or have middle knowledge of. Hence, God's plan is general insofar as the details of the plan are not specified in advance but filled out as God interacts and responds to his dynamic creation. The success of God's plan is dependent upon the actions and choices of created things, some of which God does not intend or foresee. While God is infinitely resourceful and knowledgeable about the past and present, he only knows the probability that things will turn out as he intends.

These positions represent the main approaches to characterizing God's providence. However, a variety of other theological considerations are at play in specifying the nature of God's providence. First, there are important questions about the specificity of God's providence. Does God act in creation only generally, for example, by governing through the laws of nature, or by specific divine actions at particular places and times? Is God's

\footnotetext{
${ }^{5}$ See Hasker (1989), Pinnock, et al. (2010), Sanders (1998), and Rhoda (2007). It's not clear whether there are any proponents of open theism among historical Muslim or Jewish theologians. Abd al-Jabbar (eleventh century) and Gaylan ed-Dimaski (eighth century) may hold views closest to open theism in Islam. In Judaism, Ibn Ezra (twelfth century) and Levi ben Gerson (fourteenth century) may be proponents.
} 
providence primarily aimed at maintaining the order of creation as a whole or also aimed at promoting the flourishing of individual creatures? Second, there are questions about God's causal interaction with the created world. Does God's intervention in creation involve suspending or breaking the laws of nature? What is the nature of these laws? Are they mere regularities or are they necessary connections between universals or are they probabilistic? Third, there are questions about God's relation to time. One view is that God is in time and his eternality consists in his existing at every time from the past through the future with no beginning or end. A rival view is that God exists timelessly, that is, God transcends time, existing not at any temporal location but in a timeless state (cf. Craig 2009, 145). Advocates of (Super) Meticulous Providence adopt different positions on this question. Answering the question about God's relation to time helps answer the question about how God knows the future, for example, by prediction, by direct acquaintance, by perception, or by timeless apprehension. Open Theists deny that God exists timelessly and typically adopt 'tensed' views of time, such as those on which the future is non-existent or at least indeterminate, for example, presentism or growing block theory.

We take no stand on which view of providence is correct or which views are 'orthodox.' These seem to be the main views of providence on offer and we only intend to consider their compatibility or incompatibility with ontological randomness.

\subsection{The Problems}

The basic structure of the problem that randomness is supposed to pose for God's providence can be stated as follows:

(1) There are instances of ontological randomness.

(2) If God is provident, then there are no instances of ontological randomness.

(3) Therefore, God is not provident.

If one thinks that God could not but be provident (given his choice to create), securing (3) would allow the defender of such an argument to draw the stronger atheological conclusion,

(4) Therefore, God does not exist. 
We will concern ourselves with arguments seeking to establish (3) but leave it open that such arguments could be further developed to deduce (4) from (3).

Like the problem of evil, randomness might be used to generate an evidential, rather than a logical, problem for God's providence. Such problems might take the form of an inductive argument, a probabilistic argument, or an inference to the best explanation argument that have the conclusion that it is unlikely that God is provident. We formulate the problems below in terms of logical incompatibility for the sake of simplicity but recognize that suitable evidential versions of the problems can be developed.

We also assume, for the sake of argument, that there are in fact instances of ontological randomness such as those discussed in Sect. 3.2. So we assume that (1) is true or likely to be true. The arguments we consider below constitute ways of defending premise (2), pitting specific forms of randomness against specific aspects of God's providence, especially his power, knowledge, and perfect goodness. In discussing these arguments, we evaluate how effective they are against the different conceptions of God's providence presented in Sect. 3.3.

\subsubsection{Power}

God's providence involves his power insofar as God exercises control or governance over the unfolding of creation. The first argument contends that randomness is incompatible with God's control of how the created world unfolds:

Argument from Control: Suppose that there are ontologically random events, in the sense of randomness ${ }_{I}$. If there are such events, then nothing and no one, including God, has control over whether such events occur. Such events are not determined to be the case and so not predictable; they just happen. If there is pervasive randomness in the world, then God lacks control over much of the world's unfolding. If God lacks control over how much of the world unfolds in this sense, then there is no way for God to guarantee that his plan for the world comes to fruition. But such a guarantee is required for God to be provident.

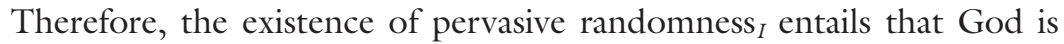
not provident. 
The Argument from Control assumes, in the first place, a strong form of randomness, namely, metaphysical randomness ${ }_{I}$, which entails that random events are entirely indeterministic. The argument does not show, however, that God's providence is incompatible with a weaker form of randomness, for example, physical randomness ${ }_{I}$, which defines a random event as one that is indeterministic with respect to any physical factors. Such randomness is compatible with being determined to occur by some transcendent cause like God's direct activity. Some (see Byl 2003 and Jaeger 2015) have noted that there can be no empirical confirmation that an event is random ${ }_{I}$ in the stronger sense because no amount of empirical inquiry could reveal that an event is entirely indeterministic.

Does the argument, therefore, show that metaphysical randomness ${ }_{I}$ is incompatible with God's providence? It would if God's providence is taken to entail that the world is deterministic. Some versions of Super Meticulous Providence, for example, Theological Determinism, have this feature. But Meticulous and General views of Providence both countenance indeterminism. The Molinist, for example, can allow that there are events that are the result of entirely indeterministic processes but insist that God knows prior to creation which events will indeterministically occur in a given set of circumstances. Open Theists already deny that God has exhaustive knowledge of the actual future on account of the indeterminacy of free human action. Presumably, they would also allow for nonhuman indeterminacy. The indeterminacy of metaphysical randomness ${ }_{I}$ appears to pose no special problem for Open Theists.

The central move in the argument is to connect randomness with lack of control. Random ${ }_{I}$ events may be uncontrollable in the sense that they 'just happen,' that is, by not being determined to happen. But as we noted in Sect. 3.2 above, it is important to distinguish the genus, indeterministic randomness, from the species, arbitrary randomness ${ }_{I}$, for it is only the latter that 'just happen' in the sense that the probability of the event is completely unconnected to antecedent states of the world. Random ${ }_{I}$ events that are not arbitrary may still be governed by statistical laws and have their probability determined by what precedes them (as well as the natures of the entities involved in these events). Consequently, God may know the likelihood of random $_{I}$ events that are not arbitrarily random . $_{\text {. }}$

The notion of 'control' operative in the Argument from Control is unspecified. Certainly, God would have control over a world of random events in the sense that he could remove his sustaining activity and let the 
world go out of existence. ${ }^{6}$ Power to employ such a 'nuclear option' is, however, not what defenders of God's providence have in mind when they attribute to God control over creation. The argument assumes that God is, as it were, at the mercy of the outcomes of random processes, unable to intervene. But on many views of providence God controls creation not simply through the general laws and the initial state of the world, but also through direct action at specific times and places. ${ }^{7}$ Hence, even if a random $_{I}$ event 'just happens,' God need not sit idly by if such an event is not part of his plan. If God foresees a random ${ }_{I}$ event will occur (or knows it has a high probability of occurring) he may preemptively intervene to diminish or neutralize its causal effects. The point is that the above argument assumes that God's control over the world is exhausted by the laws and mechanisms he put in place at the initial creation. ${ }^{8}$

Next, the argument relies on 'pervasive' randomness $_{I}$ to generate a problem for God's control. It is difficult to assess how much randomness ${ }_{I}$ would be required to wrest providential control from God. In the first place, we would need to know what sorts of events are taken to be ran$\operatorname{dom}_{I}$ : ordinary physical events involving inanimate objects or human choices that may determine one's eternal destiny? God may tolerate large amounts of randomness ${ }_{I}$ in matters that make no difference to his ultimate plan, for example, the shape of a stone smoothed by flowing water over millennia, but not in events central to his plan, for example, the course of human history. Even if randomness ${ }_{I}$ is pervasive with regard to events central to his plan, the worry only has bite if God is unable to mitigate or compensate for randomness $s_{I}$ that results in effects counter to his plan.

Second, for 'pervasive' randomness $s_{I}$ to generate a problem for God's providence we would need to know at what level of reality randomness ${ }_{I}$ pervades, for example, the quantum, chemical, biological, psychological, or social levels. Then we would need to know whether and how randomness $_{I}$ at one level influences events at another level. Even if the quantum

\footnotetext{
${ }^{6}$ See Davison (1999) for a taxonomy of different forms of control relevant to providence.

${ }^{7}$ The literature on 'special divine action,' that is, whether God intervenes in creation at specific times and places, is vast and can't be adequately addressed here. Pollard (1958), Russell (2008), Bartholomew (2008), Murphy (2009), and Polkinghorne (2005) hold that indeterminacy at various levels of reality provides God an entry point for providential action in the world. See Saunders (2002), Koperski (2015), and Jaeger (2015) for critical discussion.

${ }^{8}$ This is not to say that there are no challenges for thinking that God's intervention in the world is pervasive and constant. See van Inwagen $(2006,120)$ and Swinburne $(2004$, chapter 8) for discussion.
} 
level displays pervasive metaphysical randomness ${ }_{I}$, higher levels of reality may not display the same randomness ${ }_{I}$. Some physicists contend that macro systems do not display the kind of uncertainty and indeterminism observed at the quantum level because quantum effects are 'washed out' as systems interact with each other. To make the argument compelling, its defender needs to identify a form of randomness ${ }_{I}$ that pervades certain created phenomena whose activity plays a crucial role in God's plans.

The most familiar argument of this kind concerns randomness in the evolution of life on earth:

Argument from Biological Evolution: Evolutionary theory is our best science regarding the development of life on earth. According to evolutionary theory, species evolve by a process of natural selection involving mutations that are random in the sense that they do not occur for the sake of the fitness of individuals or species. The very mechanism that drives the development of life on earth operates 'blindly' or 'unconcerned' with the existence and well-being of human beings (and of every other species for that matter). Consequently, if God only relies on the mechanisms underlying evolution to populate the earth, God cannot control what species are produced. Hence, when God created the earth, there is no way for God to guarantee (though God could have knowledge of the probability) that human beings-much less particular individual persons-would emerge from the evolutionary process. Therefore, our best scientific accounts of the development of life on earth, if true, entail that God was simply fortunate to have created a world in which human beings emerged. Being fortunate in this sense is incompatible with providential control.

Suppose evolution involves metaphysical randomness ${ }_{I}$, for example, it involves some mutations that are the result of entirely indeterministic processes at the quantum level that "reverberate 'upwards' into biological structures" (Wessling and Rasmussen 2017, 985). If that is the case, then Super Meticulous Providence faces a problem insofar as it is generally incompatible with metaphysical randomness ${ }_{I}$. Meticulous and General views of Providence do not face this problem, as we've seen. However, General Providential views like Open Theism do face the problem that if natural selection involves mutations that are metaphysically $\operatorname{random}_{I}$ then God will not have full knowledge of how the evolutionary process will unfold and hence diminished ability to direct the evolutionary process. $\mathrm{He}$ 
may know how things could go or how likely they are to go a certain way, but he may not know with certainty that humans (or anything much like us) would be produced by evolution. ${ }^{9}$

The Argument from Biological Evolution assumes that it was part of God's plan to create human beings in particular, rather than creatures like us in certain respects, for example, finite, conscious, rational, free, and embodied creatures. Super Meticulous Providence would seem to share this assumption insofar as it depicts God as intending and determining every event to occur for a reason. The question is whether God would or could issue a general decree like this: 'let there be finite, conscious, rational, free, embodied beings who can be in a relationship with me. ${ }^{10}$ Such a decree would be general in that it doesn't specify the exact nature of the creatures that satisfy this description. There is reason to think, however, that Super Meticulous views of Providence cannot have God issue general decrees like this. Suppose God issues a decree such as "let there be X creatures, or Y creatures, or, Zs, or ... so long as they are finite, conscious, free, and embodied, etc." Such a decree would be realized so long as Xs, Ys, or $\mathrm{Zs}$, and so on were produced. But if God did not also determine which particular kind of creatures are produced, then there would be events that undetermined by God, namely, those leading to the production of those creatures. That is incompatible with the commitment to God's complete deterministic control over creation of Super Meticulous Providence.

Meticulous Providential views depict God as choosing among a range of feasible worlds to actualize. Prior to creation, God could actualize a number of worlds, some in which human beings exist, others in which different creatures, like us in certain important respects, exist. But after the choice to actualize a certain world is made, there is no possibility or potential that the evolutionary process would produce anything other than what that world specifies it contains. Hence, for the Molinist, God could not give the general decree for a particular world given that each world is completely specified and individuated prior to actualization (in part because of its unique profile of true counterfactuals of indeterminism). Nevertheless, the Molinist rejects the claim that God is 'fortunate' to have created a world with human beings. However, he is 'fortunate' to have a feasible world like this one to actualize on account of the independence of the truth of the counterfactuals of indeterminism from his will.

\footnotetext{
${ }^{9}$ See Clark (2014) for discussion of this issue.

${ }^{10}$ van Inwagen $(1988,48 \mathrm{ff}$.) contains a similar discussion of God's general decrees.
} 
General Providential views seem to have the best chance of pursuing the response being considered. God can issue the general, open ended decree 'let there be Xs, Ys, or Zs ...' because there are no facts of the matter about what creatures will be produced in an indeterministic world at the initial creation. Depending on how indeterministic events unfoldwhich God does not know ahead of time-this very world will produce Xs, Ys, or Zs, and so on. Hence, Open Theists can adequately resist the charge that God's plan for this world had to involve the creation of human beings rather than some other creatures.

\subsubsection{Knowledge}

The following argument seeks to show that there is an incompatibility between randomness and God's omniscience, which is traditionally taken to be entailed by his providence:

Argument from Unpredictability: Suppose that there are metaphysically random $_{I}$ events. If such events occur, then no one, including God, can know prior to their occurrence that they will occur. Therefore, no one, including God, can know prior to their occurrence that metaphysically random ${ }_{I}$ events will occur. Therefore, God does not have complete foreknowledge in a world in which metaphysically random $_{I}$ events occur. Therefore, God is not omniscient.

The Argument from Unpredictability assumes that God's foreknowledge is a matter of predicting future events. But few views of providence depict God's foreknowledge as a matter of prediction, where prediction of event $\mathrm{E}$ is a matter of knowing that $\mathrm{E}$ will occur on the basis of complete knowledge of the world prior to E's occurrence and the relevant laws. Simple foreknowledge views attribute to God knowledge of future events, not by prediction ${ }^{11}$ but by direct apprehension of or acquaintance with actual concrete events. Molinists, likewise, deny that God foreknows by prediction. God's providential control over creation

${ }^{11}$ Aquinas (1912, I, 14, 7) says that God's foreknowledge is not 'discursive,' that is, "God does not derive his knowledge by deducing conclusions from other things that he knows" (Wierenga 2018). See Hunt (2009) for defense of simple foreknowledge, the view that God has exhaustive knowledge of the actual future but not middle knowledge. 
consists in his free knowledge and his middle knowledge of what undetermined events will take place in certain circumstances. Moreover, if one adopts a timeless view of God, then one denies that God believes anything at a time (insofar as God lacks any temporal properties whatsoever). Rather, God has a complete atemporal grasp of all temporal events 'at once' or 'simultaneously' (Zagzebski 2017). God's atemporal knowledge of an event is not dependent on there being a chain of events determining the event to occur; God could know that the event occurred even if the event were undetermined by prior events (and even if it were random in the strongest sense, metaphysically arbitrarily $\operatorname{random}_{I}$ ). For God's knowledge is not dependent on prediction or foreknowledge if God is timeless.

The argument also presupposes that an adequate account of God's omniscience requires him to have complete knowledge of the actual future. But Open Theists deny that there is any knowledge of the actual future for God to have because they think there is no actual future (and thus no truth regarding the actual future) to be known. This, they hold, is consistent with God's omniscience. Moreover, Open Theists think that it is a benefit of their account that there is no knowledge of the actual future for God to have. This makes room, they contend, for free human action and the autonomy of creation and consequently for genuine divine responsiveness and relationship. The point here is that the unpredictability of random events need not pose a challenge to God's omniscience-on any view of providence-without the widely rejected assumption that God foreknows (if he foreknows at all) by prediction.

But there is another way in which randomness may be incompatible with God's omniscience, understood as including exhaustive foreknowledge of the actual future. God's foreknowledge is thought to be infallible. That is, if God believes something of the future, then he could not be wrong about it. A plausible view about the past is that it is fixed such that whatever is past is necessary as of the present-'now-necessary' or 'accidental necessity.' 12 With these assumptions we can formulate an argument for thinking that God's foreknowledge is incompatible with metaphysical randomness $_{I}$.

\footnotetext{
${ }^{12}$ Ockham introduced the terminology of 'accidental necessity.' This is the sort of necessity that the past is supposed to have because it is closed or fixed. See Adams (1987) for helpful interpretation of Ockham on this issue.
} 
Argument from the Fixity of the Past. Suppose $e$ is a metaphysical random $_{I}$ event. Hence, $e$ is the result of an entirely indeterministic process and $e$ is one outcome among a set of possible outcomes whose occurrence has an objective probability of less than 1 and greater than 0 . Let ' $E$ ' be the proposition 'that $e$ will occur.' Assume that yesterday God infallibly believed $E$. By the necessity of the past, it is now-necessary that God infallibly believed $E$. Suppose that necessarily, if $p$ is now-necessary and $p$ entails $q$, then $q$ is now-necessary. Necessarily, if yesterday God believed $E$, then $E$. Hence, it is now-necessary that $E$. If it is now-necessary that $E$, then $e$ will occur with probability of 1 . Therefore, $e$ will occur with probability of 1 . If $e$ will occur with probability of 1 , then $e$ is not metaphysically $\operatorname{random}_{I}$. This contradicts our original supposition. Therefore, if $e$ is metaphysically random ${ }_{I}$, then God cannot foreknow that $e$ will occur.

Readers familiar with the freedom and foreknowledge debate will recognize this argument as a version of the argument for theological fatalism. ${ }^{13}$ Some of the responses available to compatibilists about freedom and foreknowledge are available to compatibilists about foreknowledge and randomness. For instance, one could deny that there are any future contingent truths like $E$. That is the route Open Theists take. Consequently, they have a straightforward (but not uncontroversial) way to respond to the argument. Super Meticulous views of providence are in a more difficult position insofar as they deny that there are any non-determined events. That is, the mere supposition that there are events that have an objective probability of less than 1 and greater than 0 is incompatible with Theological Determinism.

Those who deny Molinism but affirm God's foreknowledge have at their disposal the Ockhamist response to draw a distinction between 'hard' facts about the past (those solely about the past) and 'soft' facts about the past (those that are partly about the future) (see Plantinga 1986). One response to the freedom and foreknowledge question is to reject the principle that to be free one must have alternative possibilities available to them. The above argument does not rely on this principle since it does not target free will. Instead, the analogous move in the argument concerns the objective probability of the metaphysically random $_{I}$ event, namely, that the event be one among a number of possible outcomes whose probability is

\footnotetext{
${ }^{13}$ In fact, this argument directly parallels the argument for theological fatalism formulated by Zagzebski (2017).
} 
less than 1 and greater than 0 . It appears that there's no plausible way to get out of the argument by denying that metaphysically random ${ }_{I}$ events need to have an objective probability of less than 1 and greater than 0 . That would simply be to reject the notion of randomness being considered, to change the subject to another notion of randomness.

There is a similar argument that targets Molinism directly:

Argument from Middle Knowledge: Suppose $e$ is a metaphysical random r $_{I}$ event. Hence, $e$ is the result of an entirely indeterministic process and $e$ is one outcome among a set of possible outcomes whose occurrence has an objective probability of less than 1 and greater than 0 . Suppose God has middle knowledge of the following counterfactual of indeterminism $E^{*}$ : 'if circumstances $C$ were to obtain, then $e$ would non-deterministically occur.' Suppose God actualizes a world $w$ that contains $E^{*}$. If God actualizes $w$, the objective probability of $e$ is 1 . Therefore, the objective probability of $e$ is 1 . This contradicts our original supposition. Therefore, if $e$ is metaphysically random ${ }_{I}$, then God cannot middle know $E^{*}{ }^{14}$

The crux of this argument is that when God actualizes a world in which a certain counterfactual is true, the objective probability of the indeterminate event is 1 in that world. This just seems to be a consequence of the Molinist's commitment to a risk free-view of providence. God knows how things will turn out once he makes certain circumstances obtain, despite the fact that the counterfactuals constituting his middle knowledge are contingent. Therefore, his choice to actualize a certain world makes the objective probability of an event named in the consequent of a counterfactual of indeterminism be 1 , which means that God's middle knowledge of random events undermines the possibility of those events being metaphysically $\operatorname{random}_{I}$ (though not necessarily that they are physically random ${ }_{I}$ ).

\subsubsection{Goodness}

A final class of arguments concern the connection between randomness and God's goodness or wisdom. One argument focuses on evolutionary randomness to generate a problem for God's good and wise governance of creation.

\footnotetext{
${ }^{14} \mathrm{Cf}$. Koons (this volume) for a similar challenge to the Molinist way of handling randomness.
} 
Argument from Evolutionary Evil: Evolutionary theory is our best science regarding the development of life on earth. According to evolutionary theory, species evolve by a process of natural selection involving mutations that are relatively $\operatorname{random}_{P}$; they do not occur for the sake of the fitness of individuals or species. The process of natural selection results in massive amounts of suffering and death over long periods of time. God is said to have providential control over creation insofar as God is said to lovingly guide creation toward a good end. The process of natural selection appears to conflict with God's providential control over creation since such a God would not use such a wasteful and brutal method for populating and sustaining the creation when more direct and less wasteful/brutal means are at his disposal. If God exists and has providential control over creation, we would not expect to see the amounts and kinds of waste, suffering, and haphazardness we find in the evolutionary records. In particular, it seems that our best scientific theory of the development of life on earth is in tension with (is evidence against) God's good and wise guidance of creation.

Arguments like this challenge all conceptions of God's providence since they target God's means for realizing his goals. Super Meticulous views of providence face the greatest challenge since they hold that God intends and determines every event to occur. Given the high degree of control God has over creation, we would not expect him to use these means to achieve his goals. Common responses to this argument appeal to the value of an autonomous creation (Wessling and Rasmussen 2017). But on Super Meticulous views of providence like Theological Determinism, creation has no autonomy. Such responses are not available to Super Meticulous Providence of this sort.

Defenders of Meticulous Providence can grant that creation has a certain amount of autonomy insofar as they hold that God does not control the truth-values of conditionals concerning what indeterministic events will occur in what circumstances. But despite that autonomy, Molinists still hold that God chose to actualize this world with its unique profile of true counterfactuals of indeterminism. So there remains the question why a good and wise governor would actualize a world with wastefulness and brutality of the evolutionary record we in fact find. General Providence attributes to God at least control over the unfolding of creation of the various views of providence. Such views seem to be able to fully account for the autonomy of creation. But the concern the above argument 
presents for General Providence is that a good and wise creator would create a world that he had so little control over, that is, a world he knew had the possibility of unfolding in the (putatively) problematic way we observe.

On all conceptions of providence, God is thought to lovingly and wisely guide creation to its intended goal. However, if random events are purposeless, ${ }^{15}$ then we might question whether randomness is compatible with God's loving and purposeful plan:

Argument from Purposelessness: If there are ontologically random events (in the sense of either randomness ${ }_{I}$ or randomness $_{P}$ ), then there are events that are not part of any plan or purpose. Suppose that there are such events. If God is provident, then every event occurs for a purpose and is integrated into his loving plan for creation. So, the presence of ontological randomness entails that some events are not part of a purpose or plan, whereas God's providence entails that all events are part of a purpose or plan. Therefore, the presence of ontological randomness is incompatible with God's providence.

Traditionally, Super Meticulous views of providence are committed to every event being part of God's plan (cf. Byl 2003, 106). Is this a necessary commitment of an account of God's providence? Suppose we agree that it is. Then it appears that Super Meticulous Providence is incompatible with randomness $_{I}$ and randomness $_{P}$. If God determines every event to happen and God is rational (always acting on the basis of consistent reasons), then it follows that no event is the result of an indeterministic process and that every event occurs for a purpose. Hence, Super Meticulous Providence is incompatible with randomness ${ }_{I}$ and randomness ${ }_{P}{ }^{16}$ However, defenders of Super Meticulous Providence might push back and question the idea that because God is rational, every event he determines is determined to occur for a reason or purpose. Suppose God sets up the initial state of the world such that a unique future unfolds. It could be that as that future unfolds there occurs an event $\mathrm{E}$ that God has no purpose for: $\mathrm{E}$ is merely a causal

\footnotetext{
${ }^{15}$ Here we are only considering the purposefulness of events in terms of what purpose they occur for. We are not concerned here with God's ability to, as it were, 'repurpose' events for his aims. See van Inwagen $(1988,53)$ for a similar discussion. He draws a distinction between God's "eternal" plan and his "reactive" plan.

${ }^{16}$ Divine determination is consistent with randomness $s_{\mathrm{P}}$ where there is no purpose from a scientific or physical perspective. That is, God may have a purpose for an event that is random with regard to goals detectable to scientific investigation.
} 
byproduct of a series of events that help fulfill God's plan, but the occurrence or non-occurrence of $\mathrm{E}$ contributes nothing to realizing that plan. God would have been equally satisfied had E not occurred at all.

Similar considerations may be thought to apply to Meticulous Providence. According to Molinists, God knows what will unfold in a world prior to actualizing that world on the basis of his free and middle knowledge. The thought is that God would not actualize a world with certain events capriciously, but rather only for a purpose. Hence, even if not all events are determined to occur, God's rationality and purposefulness in actualizing a world entails that there are no purposeless events. However, the Molinist will point out that God may have a purpose in actualizing a particular world (because, say, of certain goods it contains) without having a purpose for each particular event in that world. God, suppose, chose to actualize this world for a reason, but this world contains an event that God could take or leave (or even that he'd prefer was not included). Hence, Molinism does not obviously rule out purposeless events.

Open theists, on the other hand, are not obviously challenged by the argument given above. Open theists deny that God determines or that he fore/middle knows all future events. Therefore, there may occur events that he did not intend or desire, events that play no role in realizing his plan and may even be detrimental to his plan. The possibility of $\operatorname{random}_{P}$ events seems built into the Open Theist's view of providence.

\subsection{Conclusion}

There is far more to say about each of the above arguments. Our paper surveyed the conceptual landscape of the connection between randomness and God's providence. To that extent it merely scratched the surface of the many and complex issues at play. What we have hoped to do is to identify the various factors and choice points that need to be decided upon in order to argue for the compatibility or incompatibility of ontological randomness and God's providence. Our discussion of the different forms of randomness and different conceptions of God's providence show, we think, that there is no easy route to establishing that randomness is incompatible with God's providence over the created world. ${ }^{17}$

\footnotetext{
${ }^{17}$ Thanks to the participants in Models of Providence: An Abrabamic Inquiry for the many conversations about ideas in this paper. Special thanks to Jeff Koperski, Kelly J. Clark, Scott Davison, and Chris Tucker for comments on the paper.
} 


\section{BIBLIOGRAPHY}

Adams, Marilyn. 1987. William Ockham. Vols. 1 and 2. Notre Dame: University of Notre Dame Press.

Aquinas, Thomas. 1912. The Summa Theologica of St. Thomas Aquinas. London: Burns Oates \& Washbourne.

Bartholomew, David J. 2008. God, Chance, and Purpose. Cambridge: Cambridge University Press.

Bradley, James. 2012. Randomness and God's Nature. Journal of the American Scientific Affiliation 64 (2): 75-89.

Byl, John. 2003. Indeterminacy, Divine Action and Human Freedom. Science \& Christian Belief 15 (2): 101-116.

Clark, Kelly James. 2014. Religion and the Science of Origins. New York: Palgrave Macmillan.

Craig, William Lane. 2009. Divine Eternality. In The Oxford Handbook of Philosophical Theology, ed. Michael Rea and Thomas Flint, 145-166. New York: Oxford University Press.

Davison, Scott. 1999. Divine Providence and Human Freedom. In Reason for the Hope Within, ed. Michael Murry, 217-237. Grand Rapids: Eerdmans.

Flint, Thomas. 1998. Divine Providence. Ithaca: Cornell University Press.

Hasker, William. 1989. God, Time, and Knowledge. Ithaca: Cornell University Press.

Hitchcock, Christopher. 2018. Probabilistic Causation. In The Stanford Encyclopedia of Philosophy, ed. Edward N. Zalta. https://plato.stanford.edu/ archives/fall2018/entries/causation-probabilistic/. Accessed 25 Mar 2019.

Hunt, David. 2009. The Providential Advantage of Divine Foreknowledge. In Arguing About Religion, ed. Kevin Timpe, 374-385. New York: Routledge.

Jaeger, Linda. 2015. Chance in a Created World: How to Avoid Common Misunderstandings About Divine Action. European Journal for Philosophy of Religion 7 (3): 155-169.

Judisch, Neal. 2012. Meticulous Providence and Gratuitous Evil. In Oxford Studies in Philosophy of Religion, ed. Jonathan Kvanvig, vol. 4, 55-83. Oxford: Oxford University Press.

Koons, R. forthcoming. Reconciling Meticulous Divine Providence with Objective Chance. In Abrahamic Reflections on Randomness and Providence, ed. Kelly James Clark and Jeffrey Koperski. Palgrave.

Koperski, Jeffrey. 2015. The Physics of Theism. Malden: Wiley Blackwell.

Maimonides, Moses. 1904. A Guide for the Perplexed. Translated by M. Friedlaender, 4 th revised ed. New York: Dutton.

Murphy, N. 2009. Divine Action in the Natural Order: Buridan's Ass and Schrödinger's Cat. In Philosophy, Science and Divine Action, ed. F. LeRon Shults, Nancey C. Murphy, and Robert J. Russell, 325-357. Leiden: Brill. 
Pinnock, Clark, Richard Rice, John Sanders, William Hasker, and David Basinger. 2010. The Openness of God. Downers Grove: InterVarsity Press.

Plantinga, Alvin. 1986. On Ockham's Way Out. Faith and Philosophy 3: 235-269. Polkinghorne, John. 1994. Science and Christian Belief. London: SPCK.

- 2005. Science and Providence: God's Interaction with the World. West Conshohocken: Templeton Foundation Press.

Pollard, William G. 1958. Chance and Providence: God's Action in a World Governed by Scientific Law. London: Faber and Faber.

Rhoda, Alan. 2007. The Philosophical Case for Open Theism. Philosophia 35 (3-4): 301-311.

- 2010. Gratuitous Evil and Divine Providence. Religious Studies 46 (3): 281-302.

Russell, Robert. 2002. God's Providence and Quantum Mechanics. Counterbalance. https://counterbalance.org/physics/qmprovid-frame.html. Accessed 25 Mar 2019.

- 2008. Quantum Physics and Theology of Non-Interventionalist Objective Divine Action. In Oxford Handbook of Religion and Science, ed. Philip Clayton, 579-595. New York: Oxford University Press.

Sanders, John. 1998. The God Who Risks. Downers Grove: InterVarsity Press.

Saunders, Nicholas. 2002. Divine Action and Modern Science. New York: Oxford University Press.

Swinburne, Richard. 2004. The Existence of God. 2nd ed. Oxford: Oxford University Press.

Van Inwagen, Peter. 1988. The Place of Chance in a World Sustained by God. In Divine and Human Action, ed. Thomas Morris, 211-235. Ithaca: Cornell University Press.

- 2006. The Problem of Evil: The Gifford Lectures. New York: Oxford University Press.

Vicens, Leigh. 2014. Theological Determinism. In Internet Encyclopedia of Philosophy. https://www.iep.utm.edu/theo-det/. Accessed 25 Mar 2019.

Wessling, Jordan., and Joshua Rasmussen. 2017. A Randomness-Based Theodicy for Evolutionary Evils. Zygon 52 (4): 984-1004.

Wierenga, Edward. 2018. Omniscience. In The Stanford Encyclopedia of Philosophy, ed. Edward N. Zalta. https://plato.stanford.edu/archives/spr2018/entries/ omniscience/. Accessed 25 Mar 2019.

Zagzebski, Linda. 2017. Foreknowledge and Free Will. In The Stanford Encyclopedia of Philosophy, ed. Edward N. Zalta. https://plato.stanford.edu/ archives/sum2017/entries/free-will-foreknowledge/. Accessed 25 Mar 2019. 
Open Access This chapter is licensed under the terms of the Creative Commons Attribution 4.0 International License (http://creativecommons.org/licenses/ by $/ 4.0 /)$, which permits use, sharing, adaptation, distribution and reproduction in any medium or format, as long as you give appropriate credit to the original author(s) and the source, provide a link to the Creative Commons licence and indicate if changes were made.

The images or other third party material in this chapter are included in the chapter's Creative Commons licence, unless indicated otherwise in a credit line to the material. If material is not included in the chapter's Creative Commons licence and your intended use is not permitted by statutory regulation or exceeds the permitted use, you will need to obtain permission directly from the copyright holder. 